\title{
Mengukur Kinerja Pra Merger Tiga Bank Umum Syariah dan Pengaruhnya Terhadap Return on Asset
}

\author{
Hanif Artafani Biasmara ${ }^{1}$, Pande Made Rahayu Srijayanti ${ }^{2}$ \\ ${ }^{1,2}$ Fakultas Ekonomi dan Bisnis, Telkom University \\ e-mail: ${ }^{1}$ hanifartafani@student.telkomuniversity.ac.id, ${ }^{2}$ panderahayu@ student.telkomuniversity.ac.id
}

\begin{tabular}{ccc}
\hline Diterima & Direvisi & Disetujui \\
$24-01-2021$ & $11-03-2021$ & $14-03-2021$ \\
\hline
\end{tabular}

\begin{abstract}
Abstrak - Pada tahun 2020, telah ditetapkan pelaksanaan merger antara tiga Bank Umum Syariah yang merupakan anak perusahaan dari Bank Badan Usaha Milik Negara (BUMN). Dimana ketiga bank tersebut adalah PT Bank Syariah Mandiri, PT Bank BRIsyariah, Tbk, dan PT Bank BNI Syariah. Penelitian ini dilakukan untuk mengukur kinerja keuangan ketiga bank tersebut sebelum dilakukannya merger dan pengaruhnya terhadap Return on Asset (ROA). Dalam penelitian ini, kinerja keuangan akan diukur dengan variabel Capital Adequacy Ratio (CAR), Financing to Deposit Ratio (FDR), Non Performing Financing (NPF), Biaya Operasional dan Pendapatan Operasional (BOPO), dan persentase pertumbuhan Dana Pihak Ketiga (DPK). Data yang digunakan dalam penelitian ini merupakan data sekunder yang diperoleh melalui laporan keuangan tahunan dari masing-masing bank dengan periode tahun 2015-2019. Dimana data diolah dan dianalisis dengan menggunakan Regresi Linear Data Panel melalui perangkat lunak Stata 16. Kinerja ketiga Bank Umum Syariah sebelum dimerger menunjukkan hasil yang baik. Selama lima tahun terakhir CAR dan NPF memiliki kinerja yang memuaskan. FDR dan BOPO berada sedikit melenceng dari batas minimum ataupun maksimum. Berikutnya, pertumbuhan DPK rata-rata sebesar 15, 89333\%. Seluruh variabel kinerja bank tersebut setelah dilakukan pengolahan data, menunjukkan bahwa variabel CAR, FDR, NPF, BOPO, dan pertumbuhan DPK bersama-sama memiliki pengaruh signifikan terhadap ROA. Sedangkan secara parsial, CAR, NPF, dan pertumbuhan DPK tidak memiliki pengaruh signifikan terhadap ROA. Tetapi FDR dan BOPO memiliki pengaruh signifikan terhadap ROA. Dimana melalui penelitian ini diharapkan dapat menjadi pertimbangan bagi PT Bank Syariah Indonesia Tbk dalam upaya memperoleh kinerja yang baik dan pertumbuhan profitabilitas yang tinggi
\end{abstract}

Kata Kunci: CAR, FDR, NPF, BOPO, Pertumbuhan DPK, ROA, Bank Umum Syariah

\begin{abstract}
In 2020, the implementation of a merger between three Islamic Commercial Banks which are subsidiaries of the State-Owned Enterprise (BUMN) Bank has been determined. Where the three banks are PT Bank Syariah Mandiri, PT Bank BRIsyariah, Tbk, and PT Bank BNI Syariah. This research was conducted to measure the financial performance of the three banks before the merger, and their effect on Return on Assets (ROA). In this study, financial performance will be measured by the variable Capital Adequacy Ratio (CAR), Financing to Deposit Ratio (FDR), Non-Performing Financing (NPF), Operational Costs and Operating Income (OEOI), and the percentage growth in Third Party Funds (TPF).The data used in this study is secondary data obtained through the annual financial reports of each bank for the period 2015-2019. Where the data is processed and analyzed using Linear Data Panel regression through Stata 16. The performance of the three Islamic Commercial Banks before the merger showed good results. Over the last five years, CAR and NPF have performed satisfactorily. FDR and BOPO have slightly deviated from the minimum or maximum limits. Next, the growth in deposits was an average of $15.89333 \%$. All of these bank performance variables, after data processing, show that the variables CAR, FDR, NPF, OEOI, and TPF growth together have a significant effect on ROA. Meanwhile, partially, CAR, NPF, and TPF growth have not a significant effect on ROA. However, FDR and BOPO have a significant effect on ROA. Where through this research it is hoped that in the future it can be a consideration for PT Bank Syariah Indonesia, Tbk to obtain good performance and high profitability growth.
\end{abstract}

Keywords: CAR, FDR, NPF, OEOI, TPF Growth, ROA, Islamic Commercial Banks

\section{PENDAHULUAN}

Gagasan hadirnya bank dengan konsep Syariah di Indonesia telah dilakukan mulai tahun 1980 dengan adanya diskusi-diskusi mengenai basis perekonomian Islam melalui Bank Islam (Suryani, 2012). Lalu hal tersebut dapat terealisasikan melalui PT Bank Muamalat Indonesia (BMI) yang hadir sebagai pionir Bank Syariah di Indonesia pada tahun 1991. Hadirnya Bank Muamalat Indonesia pada 
waktu, belum mampu mendapatkan atensi di dalam industri perbankan dan memiliki performa yang stasioner. Namun setelah terjadinya krisis ekonomi pada tahun 1998, Bank Muamalat Indonesia semakin memperoleh minat dari masyarakat. Akibat adanya krisis ekonomi pada tahun 1998, bank-bank yang menerapkan operasional secara konvensional banyak yang harus gulung tikar. Berbanding terbalik dengan Bank Muamalat Indonesia yang mampu bertahan dalam kondisi krisis. Sehingga menjadikan beberapa bank umum konvensional lainnya beralih dengan operasional Syariah (Aulia, 2020).

Setelah ditetapkan Undang-Undang Nomor 10 Tahun 1998 Tentang Perbankan, bermunculan bank-bank yang menggunakan prinsip Syariah. Tidak terkecuali Bank BUMN untuk membentuk anak perusahaan sebagai bank umum dengan prinsip Syariah. Pada tanggal 1 November 1999, PT Bank Syariah Mandiri resmi beroperasi diawali dengan adanya merger empat bank yang terdiri atas Bank Dagang Negara, Bank Bumi Daya, Bank Exim, dan Bank Pembangunan Indonesia sebagai PT Bank Mandiri (Persero) Tbk. Lalu PT Bank Susila Bakti yang merupakan bagian dari Bank Dagang Negara, dialihkan menjadi PT Bank Syariah Mandiri. Sampai dengan Januari 2021 PT Bank Mandiri (Persero) Tbk. memiliki saham mayoritas sebesar 99,99999983\% dan PT Mandiri Sekuritas mempunyai saham sebesar $0,00000017 \%$.

Bank Umum Syariah yang merupakan bagian dari Bank BUMN selanjutnya adalah PT Bank Rakyat Indonesia (Persero) Tbk yang berdiri sebagai hasil akuisisi oleh PT Bank Rakyat Indonesia (Persero) Tbk terhadap Bank Jasa Arta pada tanggal 19 Desember 2007. PT Bank BRIsyariah Tbk mulai beroperasi pada 17 November 2008. PT Bank BRIsyariah Tbk. mencatatkan dirinya dalam Bursa Efek Indonesia dengan melaksanakan Initial Public Offering (IPO) pada tanggal 9 Mei 2018. Sebagai induk perusahaan, PT Bank Rakyat Indonesia (Persero) Tbk memiliki kepemilikan saham sebesar 73\%. Lalu kepemilikan saham oleh publik, baik lokal maupun asing sebesar 27\% per 30 November 2020.

Berikutnya Bank Umum Syariah yang merupakan bagian dari Bank BUMN adalah PT Bank BNI Syariah. Pada mulanya PT Bank BNI Syariah merupakan UUS (Unit Usaha Syariah) pada tahun 2000. Lalu pada tahun 2010 status PT Bank BNI Syariah berganti menjadi BUS (Bank Umum Syariah) dan pada tanggal 19 Juni 2010 telah mulai beroperasi. Pemilik saham mayoritas sebesar 99,95\% adalah PT Bank Negara Indonesia (Persero) Tbk. Sedangkan saham sebesar $0,05 \%$ dimiliki oleh PT BNI Life Insurance.

Pada tahun 2020, terjadi merger antara tiga Bank Umum Syariah anak perusahaan Bank BUMN. Dimana pada akhir tahun 2020, telah ditetapkan nama dari hasil merger ketiga bank tersebut yaitu PT Bank Syariah Indonesia Tbk. Merger yang dilakukan oleh ketiga Bank Umum Syariah tersebut, dinilai oleh
Gubernur Bank Indonesia mampu untuk meningkatkan perekonomian dan keuangan Syariah, serta memperkuat perbankan Syariah di Indonesia. Selain itu, potensi untuk terciptanya halal value chain dalam memacu keuangan Syariah juga akan semakin terbuka lebar (Bisnis Tempo, 2020)

Adanya merger antara tiga Bank Umum Syariah yang terdiri atas PT Bank Syariah Mandiri, PT Bank BRIsyariah Tbk, dan PT Bank BNI Syariah, yang melatarbelakangi penulis dalam melakukan penelitian ini. Dimana penelitian ini dilakukan untuk mengukur kinerja keuangan ketiga bank tersebut sebelum dilakukannya merger. Selain itu, penelitian ini juga akan mengidentifikasi pengaruh kinerja keuangan tiga Bank Umum Syariah anak perusahaan BUMN tersebut, terhadap Return on Asset (ROA).

\section{Rasio Keuangan}

Rasio keuangan merupakan rasio yang membandingkan angka dalam laporan keuangan dengan cara membagi satu angka dengan angka lainnya (Kasmir, 2012). Rasio keuangan merupakan metode yang sering digunakan untuk mengetahui hubungan antara pos-pos tertentu yang ada dalam laporan keuangan yang selanjutnya akan digunakan untuk mengevaluasi kondisi keuangan dan kinerja suatu perusahaan. Adapun bentuk-bentuk dari rasio keuangan seperti rasio likuiditas, rasio solvabilitas, rasio aktivitas, dan rasio profitabilitas (Sanjaya, 2017). Penelitian ini menggunakan rasio capital adequacy ratio (CAR), financing to debt ratio (FDR), non performing financing (NPF), biaya operasional pendapatan operasional (BOPO), dan dana pihak ketiga (DPK) sebagai variabel independen yang merupakan rasio kinerja keuangan dan menggunakan return on asset (ROA) sebagai rasio profitabilitas.

\section{a. Capital Adequacy Ratio (CAR)}

Menurut Dendawijaya (2009), CAR merupakan rasio yang menunjukkan seberapa jauh aktiva suatu bank yang mengandung risiko dibiayai oleh modal sendiri disamping memperoleh dana dari sumber lain di luar bank. Sehingga CAR dapat diukur dengan jumlah modal yang dimiliki oleh bank yang mana modal tersebut digunakan untuk risiko kehilangan aset produksi (Tampubolon \& Prima, 2020). Untuk mengukur rasio CAR dapat menggunakan rumus sebagai berikut:

$$
C A R=\frac{\text { Modal }}{\text { Aktiva tertimbang menurut risiko }} \times 100 \%
$$

Dengan kata lain, rasio CAR merupakan rasio yang mewakili modal suatu bank. Yundi dan Sudarsono (2018) mengatakan bahwa modal merupakan salah satu faktor penting dalam mengembangkan suatu bisnis dan menampung risiko kerugian, semakin tinggi nilai CAR maka semakin tinggi atau kuat kemampuan suatu bank dalam menanggung risiko dari aset produktif yang berisiko. 


\section{b. Financing to Debt Ratio (FDR)}

Menurut Azmy (2018), rasio financing to debt ratio mengukur kemampuan bank dalam menyalurkan dana pihak ketiga terhadap pembiayaan. FDR merupakan rasio yang berfungsi untuk mengukur komposisi suatu pembiayaan yang dibandingkan dengan jumlah dana masyarakat dan modal sendiri yang digunakan. Dengan kata lain, bank harus mampu mengelola dana yang dimiliki dengan cara mengoptimalkan penyaluran agar lukuiditas bank tersebut tetap terjaga (Kasmir, 2012). Semakin tinggi rasio FDR maka semakin rendah kemampuan likuiditas suatu bank. Rasio FDR dapat diukur menggunakan rumus sebagai berikut:

$F D R=\frac{\text { Jumalh pembiayaan yang diberikan }}{\text { Total dana pihak ketiga }} \times 100 \%$

\section{c. Non Performing Financing (NPF)}

Rasio NPF dalam bank syariah atau NPL (Non Performing Loan) dalam bank konvensional ini merupakan rasio yang digunakan untuk mengukur sejauh mana kemampuan suatu bank dalam mengelola kredit atau pembiayaan bermasalah (Wardhani \& Amanah, 2019). Berdasarkan Surat Edaran Bank Indonesia No.17/19/DPUM tanggal 8 Juli 2015 disebutkan bahwa bank umum yang baik memiliki rasio NPF kurang dari 5\%. Apabila suatu bank tidak dapat mengelola pembiayaan dengan baik, hal ini akan berdampak pada meningkatnya pembiayaan yang bermasalah. Meningkatnya pembiayaan yang bermasalah akan menyebabkan menurunnya kemampuan suatu bank dalam menghasilkan laba (Nisa Friskana \& Sudarsono, 2018). Rasio NPF dapat dihitung menggunakan rumus sebagai berikut:

$N P F=\frac{\text { Pembiayaan bermasalah }}{\text { Total pembiayaan }} \times 100 \%$

\section{d. Biaya Operasional Pendapatan Operasional (BOPO)}

Rasio BOPO merupakan rasio yang membandingkan biaya operasional dengan pendapatan operasional. Rasio ini juga menujukkan efisiensi bisnis dari suatu bank, terutama dalam pelaksanaan kredit. Efisiensi operasional atau BOPO ini akan memengaruhi kinerja suatu bank (Yusuf \& Surjaatmadja, 2018). Semakin rendah rasio BOPO, maka semakin baik bank dalam menjalankan aktivitas usahanya. Hal ini dikarenakan bank dapat menggunakan sumber daya yang ada pada perusahaan dengan efisien. Rasio BOPO dapat dihitung menggunakan rumus sebagai berikut:

$B O P O=\frac{\text { Biaya operasional }}{\text { Pendapatan operasional }} \times 100 \%$

\section{e. Pertumbuhan Dana Pihak Ketiga (DPK)}

Dana pihak ketiga (DPK) dijelaskan dalam Undang-Undang Nomor 10 Tahun 1998 mengenai Perbankan (UU Perbankan). DPK merupakan dana yang yang dihimpun oleh bank berdasarkan perjanjian penyimpanan dana dalam bentuk giro, deposito, sertifikat deposito, tabungan atau yang lainnya. Nilai yang tinggi pada DPK menunjukkan kemampuan manajemen bank dalam bentuk pembiayaan juga meningkat. Pembiayaan yang meningkat akan menambah kemampuan bank dalam menghasilkan pendapatan (Nisa Friskana \& Sudarsono, 2018).

\section{Profitabilitas}

Profit atau laba merupakan kelebihan pendapatan yang dibandingkan dengan jumlah biaya yang dikeluarkan. Profitabilitas menunjukkan kemampuan yang ditunjukkan oleh suatu perusahaan dalam memperoleh keuntungan hasil penjualan, total aset, maupun modal. Oleh karena itu analisis dari profitabilias begitu penting karena profitabilitas mengindikasikan bahwa perusahaan memiliki prospek janga panjang yang baik (Yusuf \& Surjaatmadja, 2018). Menurut Brigham dan Houston (2006) terdapat beberapa indikator yang digunakan dalam menganalisis profitabilitas perusahaan salah satunya yaitu return on asset atau ROA.

\section{a. Return on Assets (ROA)}

ROA merupakan rasio yang menunjukkan keuntungan bersih setelah pajak terhadap jumlah aktiva keseluruhan. Menurut Kasmir (2012) ROA memberikan pengukuran yang baik atas profitabilias perusahaan. Hal ini dikarenakan ROA dapat menunjukkan efektivitas manajemen perusahaan dalam mengelola aset untuk memperoleh pendapatan. Semakin besar nilai ROA, maka semakin tinggi nilai keutungan yang dicapai perusahaan tersebut berdasarkan sisi dari penggunaan aktiva (Margaretha, 2007). Rumus yang dapat digunakan dalam menghitung ROA adalah sebagai berikut:

$$
\text { ROA }=\frac{\text { Laba setelah pajak }}{\text { Total aset }} \times 100 \%
$$

\section{Penelitian Terdahulu}

Terdapat beberapa penelitian dalam menganalisis rasio keuangan terhadap profitabilitas. Seperti penelitian yang dilakukan oleh Yusuf dan Surjaatmadja (2018) yang melakukan penelitian mengenai analisis kinerja keuangan terhadap profitabilitas. Hasil penelitian tersebut menunjukkan bahwa variabel CAR, BOPO, dan FDR memiliki pengaruh terhadap profitabilitas (ROA). Meningkatnya nilai CAR akan membuat profitabilitas (ROA) juga meningkat. Dengan kecukupan modal yang tinggi, secara fleksibel bank dapat mengalokasikan dananya pada investasi yang menguntungkan. Jika bank memiliki kecukupan modal yang tinggi, diharapkan kerugian yang dialami tersebut dapat diatasi dengan modal yang dimiliki oleh bank. Rasio FDR memengaruhi ROA dikarenakan dengan adanya penyaluran pembiayaan yang maksimal maka bank juga akan mendapatkan pendapatan yang tinggi. Sedangkan variabel BOPO memengaruhi ROA karena jika BOPO meningkat 
maka ROA yang diperoleh akan berkurang. Kondisi ini terjadi karea peningkatan biaya operasional bank yang tidak diikuti dengan kenaikan pendapatan operasional akan menghasilkan laba sebelum pajak berkurang sehingga akan menurunkan ROA.

Penelitian selanjutnya dilakukan oleh Wardhani dan Amanah (2019) menjelaskan bahwa variabel NPF berpengaruh terhadap ROA. NPF merupakan rasio yang mengukur total pembiayaan bermasalah sehingga peningkatan pembiayaan bermasalah ini akan menimbulkan cadangan pembiayaan semakin besar. Kerugian pembiayaan ini akan menyebabkan penurunan laba yang berdampak pada kesehatan bank. Maka dari itu keuntungan yang berkurang akan mengakibatkan profitabilitas bank tersebut juga ikut berkurang. Sedangkan variabel lainnya yaitu CAR dan FDR tidak berpengaruh terhadap ROA.

Adapun penelitian yang dilakukan oleh Azmy (2018) mengenai pengaruh rasio keuangan terhadap profitabilitas bank Pembiayaan Rakyat Syariah. Penelitian ini menunjukkan bahwa rasio NPF dan FDR memiliki pengaruh terhadap ROA dengan arah hubungan yang negatif. Arah hubungan NPF dengan ROA yang negatif ini menunjukkan bahwa setiap Bank Pembiayaan Rakyat Syariah ini mengalami permasalahan pada pembiayaan dengan tingkat keamanan diatas 5\% sehingga akan menurunkan profitabilitas perusahaan. Sedangkan arah hubungan negatif FDR dengan ROA menunjukkan bahwa Bank Pembiayaan Rakyat Syariah di Indonesia akan mengalami kesulitan dalam mencapai profitabilitas jika tidak mampu menjaga alokasi pembiayaan kepada nasabah.

Penelitian selanjutnya yaitu penelitian yang dilakukan oleh Yanti (2020) terkait dengan profitabilias bank syariah. Penelitian ini menunjukkan bahwa variabel independen CAR, NPF, dan FDR berpengaruh terhadap ROA. Semakin tinggi nilai CAR maka semakin baik kemampuan bank tersebut dalam menanggung risiko dari aset produktif yang dimiliki bank. Kemampuan bank dalam mengelola pembiayaan yang bermasalah dapat dilihat melalui NPF. NPF dapat mengakibatkan hilangnya kesempatan bank dalam memperoleh pendapatan dari pembiayaan sehingga memengaruhi pendapatan dan ROA. Financing to deposit ratio (FDR) pada penelitian ini memengaruhi ROA dimana semakin tinggi FDR maka semakin tinggi profitabilitas bank tersebut begitu juga sebaliknya. Semkain rendah FDR maka profitabilitasnya juga berkurang.

Kemudian terdapat penelitian yang dilakukan oleh Mahmudah dan Harjanti (2016) megenai analisis rasio keuanganterhadap tingkat profitabilitas bank umum syariah. Penelitian tersebut menggunakan variabel CAR, FDR, dan DPK sebagai variabel independen. Hasil penelitian tersebut dapat diketahui bahwa CAR memengaruhi ROA yang artinya semakin tinggi CAR bank umum syariah maka semakin tinggi pula ROA bank tersebut begitu pula sebaliknya. Penelitian tersebut juga menunjukkan bahwa FDR berpengaruh signifikan terhadap ROA. Hal ini dikarenakan rata-rata FDR pada bank memiliki nilai yang tinggi sehingga memengaruhi ROA. Semakin tinggi rasio FDR menunjukkan semakin rendahnya likuiditas bank yang bersangkutan. Sedangkan variabel DPK tidak menunjukkan adanya pengaruh terhadap ROA. Hal tersebut dikarnakan bahwa tidak semua dana pihak ketiga (DPK) disalurkan dalam bentuk pembiayaan sehingga tidak dapat memengaruhi ROA.

\section{Hipotesis Penelitian}

Berdasarkan atas hasil yang dikemukakan oleh beberapa peneliti terdahulu, ditemukan keragaman dalam penelitian. Penulis mengidentifikasi adanya research gap dalam penelitian terdahulu. Sehingga untuk menjawab masalah tersebut, penulis mengemukakan dugaan sementara melalui hipotesis penelitian. Dimana dalam penelitian ini, hipotesis penelitian adalah sebagai berikut:

$\mathrm{H}_{0} 1$ : Adanya pengaruh signifikan oleh kinerja pra merger tiga Bank Umum Syariah secara simultan terhadap ROA.

$\mathrm{H}_{0}$ 2: Adanya pengaruh signifikan oleh CAR terhadap ROA.

$\mathrm{H}_{0} 3$ : Adanya pengaruh signifikan oleh FDR terhadap ROA.

$\mathrm{H}_{0}$ 4: Adanya pengaruh signifikan oleh NPF terhadap ROA.

$\mathrm{H}_{0} 5$ : Adanya pengaruh signifikan oleh BOPO terhadap ROA.

$\mathrm{H}_{0} 6$ : Adanya pengaruh signifikan oleh DPK terhadap ROA.

\section{Kerangka Penelitian}

Kerangka pemikiran yang digunakan dalam penelitian ini adalah sebagai berikut:

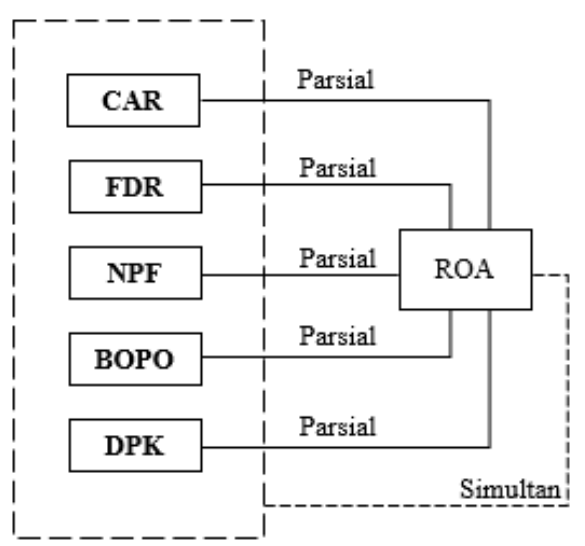

Sumber: Hasil Olahan Peneliti (2021)

Gambar 1. Kerangka Penelitian

\section{METODE PENELITIAN}

Penelitian ini memiliki tujuan deskriptif korelatif yang memberikan gambaran mengenai hubungan antar dua variabel (Sekaran \& Bougie, 
2016). Penelitian ini menggunakan CAR, FDR, NPF, BOPO, dan DPK sebagai variabel independen yang merupakan rasio keuangan. Serta menggunakan ROA sebagai variabel dependen yang merupakan rasio profitabilitas.

Populasi pada penelitian ini yaitu berdasarkan Bank Umum Syariah yang merupakan anak perusahaan BUMN diantaranya PT Bank Syariah Mandiri, PT Bank BRIsyariah, Tbk, dan PT Bank BNI Syariah. Sedangkan pemilihan sampel dilakukan dengan purposive sampling yang merupakan teknik pemilihan sampel bahwa peneliti memiliki pertimbangan khusus untuk mengambil sampel yang akan digunakan (Unaradjan, 2019). Kriteria sampel pada penelitian ini yaitu tiga bank syariah yang merupakan anak perusahaan BUMN tersebut mempublikasikan laporan keuangan perusahaan lima tahun terakhir, dimulai dari 2015-2019.

Penelitian ini termasuk penelitian yang dilakukan dengan data panel karena data panel merupakan gabungan dari data time series dan data cross section (Gujarti, 2003). Dikatakan time series karena penelitian ini menggunakan data yang memiliki seri waktu (Danang, 2013) yakni periode 2015-2019. Sedangkan cross section merupakan terdiri dari beberapa objek penelitian (Nuryanto \& Pambuko, 2018).

Langkah pertama yang dilakukan dalam penelitian ini adalah melakukan pengujian untuk memilih model terbaik dalam regresi data panel. Menurut Basuki dan Prawoto (2017) dalam pemilihan model yang paling tepat dapat menggunakan metode yang terdiri dari Uji Chow, Uji Hausman, dan Uji Lagrange Multiplier. Selanjtunya dilakukan uji asumsi klasik untuk memperoleh pengukuran yang BLUE (Best Linier Unbiased Estimator). Menurut Basuki dan Prawoto (2017) pengujian asumsi klasik terdiri atas Uji Heteroskedastisitas dan Uji Multikoliniaritas. Pengujian asumsi klasik hanya digunakan untuk pendekatan Ordinary Least Square (OLS).

Penelitian ini menggunakan data sekunder yang diperoleh dari laporan keuangan dari tahun 2015-2019 yang diterbitkan oleh masing-masing bank untuk memperoleh nilai CAR, FDR, NPF, BOPO, DPK, dan ROA.

Tabel 1. Operasionalisasi Variabel

\begin{tabular}{|c|c|c|c|}
\hline Variabel & $\begin{array}{c}\text { Jenis } \\
\text { Variabel }\end{array}$ & Indikator & Skala \\
\hline \multirow{2}{*}{ CAR } & Independen & Modal & \multirow[b]{2}{*}{ Rasio } \\
\hline & & $\begin{array}{c}\overline{\text { Aktiva tertimbang }} \\
100 \%\end{array}$ & \\
\hline \multirow[t]{2}{*}{ FDR } & Independen & Jumalh pembiayaan & \multirow[b]{2}{*}{ Rasio } \\
\hline & & $\begin{array}{c}\text { Total dana pihak ketiga } \\
\text { x } 100 \%\end{array}$ & \\
\hline \multirow[t]{2}{*}{ NPF } & Independen & Pembiayaan bermasalah & \multirow[b]{2}{*}{ Rasio } \\
\hline & & $\begin{array}{c}\text { Total pembiayaan } \\
\text { x } 100 \%\end{array}$ & \\
\hline \multirow[t]{2}{*}{ BOPO } & Independen & Biaya operasional & \multirow[b]{2}{*}{ Rasio } \\
\hline & & $\begin{array}{c}\text { Pendapatan operasional } \\
\mathrm{x} 100 \% \\
\end{array}$ & \\
\hline DPK & Independen & Pertumbuhan DPK & Rasio \\
\hline ROA & Dependen & $\begin{array}{c}\frac{\text { Laba setelah pajak }}{\text { Total aset }} \\
100 \%\end{array}$ & Rasio \\
\hline
\end{tabular}

Sumber: Hasil Olahan Peneliti (2021)

\section{HASIL DAN PEMBAHASAN}

\section{Pengukuran Kinerja}

Pengukuran kinerja pra merger tiga Bank Umum Syariah anak perusahaan BUMN dalam kurun waktu lima tahun terakhir, dilihat berdasarkan pengujian statistik. Berikut merupakan hasil pengujian statistik untuk variabel yang digunakan dalam penelitian.

Tabel 2. Hasil Uji Statistik

\begin{tabular}{|c|c|c|c|c|c|}
\hline Variable & Obs & Mean & Std. Dev. & Min & Max \\
\hline CAR & 15 & 18.23333 & 4.577418 & 12.85 & 29.73 \\
\hline FDR & 15 & 79.68933 & 4.9127 & 71.87 & 91.94 \\
\hline NPF & 15 & 2.679333 & 1.329498 & 1 & 4.97 \\
\hline BOPO & 15 & 90.71533 & 4.901237 & 81.26 & 96.8 \\
\hline DPK & 15 & 15.89333 & 5.993128 & 3.83 & 25.41 \\
\hline
\end{tabular}

Sumber: Hasil Olahan Peneliti (2021)

Berdasarkan Tabel 2, diperoleh hasil dari pengujian statistik deskriptif untuk kinerja ketiga bank dalam lima tahun terakhir. Tiga Bank Umum Syariah memiliki nilai rata-rata CAR sebesar 18,23333\%. Nilai rata-rata CAR ketiga bank dalam lima tahun terakhir dapat memenuhi batas minimal yang ditetapkan oleh Bank Indonesia yaitu sebesar delapan persen. Nilai terendah dari ketiga bank yaitu sebesar $12,85 \%$ oleh PT Bank Syariah Mandiri pada tahun 2015. Sedangkan nilai tertinggi dari ketiga bank yaitu sebesar $29,73 \%$ adalah PT Bank BRIsyariah, Tbk pada tahun 2018.

Kinerja ketiga bank dilihat dari rasio FDR, menunjukkan nilai rata-rata sebesar 79,68933\%. Hal ini menunjukkan bahwa nilai rata-rata FDR ketiga bank berada di batas nilai minimum. Dimana batas minimum nilai FDR sebesar 80\% ditetapkan oleh Bank Indonesia. Dari ketiga bank, nilai terendah untuk FDR yaitu sebesar 71,87\% oleh PT Bank BRIsyariah, Tbk pada tahun 2017. Sedangkan nilai tertinggi yaitu sebesar 91,94\% oleh PT Bank BNI Syariah pada tahun 2015.

Berikutnya, berdasarkan pengujian statistik yang telah dilakukan, diperoleh bahwa nilai rata-rata NPF untuk ketiga bank yaitu 2,679333\%. Dimana nilai tersebut masih di bawah persentase lima persen. Hal ini menunjukkan bahwa kinerja ketiga bank dalam lima tahun terakhir sangat baik. Bank yang memperoleh kinerja terbaik dari sisi NPF yaitu sebesar satu persen yaitu PT Bank Syariah Mandiri pada tahun 2019. Sedangkan dari ketiga bank dengan nilai NPF tertinggi sebesar 4,97\% yaitu PT Bank BRIsyariah, Tbk pada tahun 2018.

BOPO sendiri oleh Bank Indonesia, ditetapkan nilai maksimal sebesar 90\%. Berdasarkan Tabel 2, nilai rata-rata BOPO sebesar 90,71533\%. Hal ini menunjukkan BOPO ketiga bank berada di batas maksimum ketetapan Bank Indonesia. Dari ketiga bank, nilai BOPO terendah yaitu sebesar $81,26 \%$ oleh PT Bank BNI Syariah pada tahun 2019. Sedangkan nilai paling tinggi dalam lima tahun terakhir sebesar 96,8\% diperoleh oleh PT Bank BRIsyariah, Tbk pada tahun 2019. 
Dalam lima tahun terakhir, nilai rata-rata pertumbuhan DPK ketiga bank yaitu sebesar $15,89333 \%$. Dimana nilai pertumbuhan DPK terendah yaitu sebesar 3,83\% oleh PT Bank Syariah Mandiri pada tahun 2015. Sedangkan pertumbuhan DPK paling tinggi sebesar 25,41\% pada PT Bank BNI Syariah pada tahun 2016 .

\section{Pemilihan Model Data Panel}

Penelitian yang dilakukan merupakan regresi dengan menggunakan data panel. Sehingga langkah pertama yang dilakukan dalam penelitian ini adalah melakukan pengujian untuk memilih model terbaik dalam regresi data panel. Dimana dalam penelitian ini akan dilakukan tiga pengujian yang terdiri atas Uji Chow, Uji Hausman, dan Uji Lagrange Multiplier.

\section{a. Uji Chow}

Dalam pengujian Chow. Dilakukan perbandingan antara model Common Effect dan Fixed Effect. Dimana hipotesis dalam pengujian ini yaitu $\mathrm{H}_{0}$ diterima jika nilai (Prob > F) < alpha 0,05 yang berarti model terbaik adalah Fixed Effect. Lalu $\mathrm{H}_{0}$ ditolak jika nilai (Prob > F) > alpha 0,05 yang berarti model terbaik adalah Common Effect.

Setelah dilakukan pengujian dengan menggunakan perangkat lunak STATA 16, diperoleh nilai Prob > F sebesar 0,8282. Hal ini berarti H0 ditolak, karena nilai (Prob $>$ F) $>$ alpha 0,05. Sehingga dalam pengujian ini, model terbaik yaitu Common Effect.

\section{b. Uji Hausman}

Pengujian ini dilakukan untuk membandingkan antara model Fixed Effect dan Random Effct. Karena Fixed Effect tersisih dalam Uji Chow, pengujian ini dilakukan untuk memastikan apakah Random Effect lebih unggul dari Fixed Effect atau tidak. Jika Random Effect adalah model yang terbaik dalam pengujian ini, maka selanjutnya akan dilakukan Uji Lagrange Multiplier. Namun Jika model yang terbaik adalah Fixed Effect, maka tidak akan dilakukan Uji Lagrange Multiplier. Hipotesis dalam pengujian ini yaitu apabila nilai (Prob > Chi2) < alpha

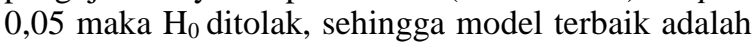
Fixed Effect. Namun apabila nilai (Prob > Chi2) > alpha 0,05 maka $\mathrm{H}_{0}$ diterima, sehingga Random Effect adalah model yang terbaik.

Setelah dilakukan pengujian, diperoleh hasil Prob > Chi2 sebesar 0,9960. Sehingga $\mathrm{H}_{0}$ diterima karena nilai (Prob > Chi2) > alpha 0,05. Hal ini menunjukkan bahwa Random Effect adalah model terbaik dalam pengujian ini. Sehingga selanjutnya akan dilakukan Uji Lagrange Multiplier.

\section{c. Uji Lagrange Multiplier}

Setelah dilakukan Uji Chow dan Uji Hausman. Selanjutnya dilakukan Uji Lagrange Multiplier untuk membandingkan model Common Effect dan Random Effect. Dimana dalam pengujian ini hipotesis yang diajukan yaitu apabila nilai (Prob > chibar2) < alpha 0,05 maka $\mathrm{H}_{0}$ diterima, sehingga
Random Effect adalah model terbaik. Namun apabila nilai (Prob > chibar2) > alpha 0,05 maka $\mathrm{H}_{0}$ ditolak, sehingga Common Effect adalah model terbaik.

Setelah dilakukan pengujian, diperoleh hasil dengan nilai Prob > chibar2 adalah sebesar 1,0000. Sehingga $\mathrm{H}_{0}$ ditolak, karena (Prob > chibar2) > alpha 0,05 . Maka dapat disimpulkan bahwa dalam penelitian ini, model yang akan digunakan adalah Common Effect.

\section{Uji Asumsi Klasik}

Berhubung model yang terpilih adalah Common Effect, sehingga perlu untuk dilakukan uji asumsi klasik. Dimana uji asumsi klasik dilakukan untuk memperoleh pengukuran yang BLUE (Best Linier Unbiased Estimator). Pengujian terdiri atas Uji Heteroskedastisitas dan Uji Multikoliniaritas.

\section{a. Uji Heteroskedastisitas}

Syarat dalam pengujian ini yaitu apabila nilai $($ Prob > chi2) > alpha 0,05 maka tidak terdapat gejala heteroskedastisitas. Namun apabila nilai (Prob > chi2) $<$ alpha 0,05 maka terdapat gejala heteroskedastisitas. Berikut adalah hasil pengujian heteroskedastisitas:

Tabel 3. Hasil Uji Heteroskedastisitas

\begin{tabular}{|c|c|}
\hline chi2(1) & 0.01 \\
\hline Prob > chi2 & 0.9355 \\
\hline
\end{tabular}

Sumber: Hasil Olahan Peneliti (2021)

Berdasarkan hasil pengujian dalam Tabel 3, menunjukkan bahwa nilai (Prob > chi2) $>$ alpha 0,05 . Sehingga data yang digunakan dalam penelitian ini tidak ditemukan gejala heteroskedastisitas.

\section{b. Uji Multikoliniaritas}

Pengujian ini dilakukan apabila variabel independen yang digunakan lebih dari satu. Syarat dalam pengujian ini yaitu apabila VIF > 10 maka terdapat multikoliniaritas. Sebaliknya jika VIF $<10$ maka tidak terdapat multikoliniaritas. Berikut adalah hasil pengujian multikoliniaritas:

Tabel 4. Hasil Uji Multikoliniaritas

\begin{tabular}{|c|c|c|}
\hline Variable & VIF & 1/VIF \\
\hline $\mathrm{X} 3$ & 4.07 & 0.245539 \\
\hline $\mathrm{X} 4$ & 4.02 & 0.248826 \\
\hline $\mathrm{X} 5$ & 1.47 & 0.680094 \\
\hline $\mathrm{X} 2$ & 1.40 & 0.715448 \\
\hline $\mathrm{X} 1$ & 1.35 & 0.738270 \\
\hline Mean VIF & 2.46 & \\
\hline
\end{tabular}

Sumber: Hasil Olahan Peneliti (2021)

Berdasarkan atas hasil pengujian dalam Tabel 4, menunjukkan bahwa tidak terdapat multikoliniaritas antar variabel independen. Hal ini dikarenakan nilai VIF untuk setiap variabel tidak lebih dari 10.

\section{Uji Hipotesis}

Pengujian selanjutnya adalah uji hipotesis. Dimana dalam uji hipotesis terdiri atas Analisis 
Koefisien Determinasi $\left(\mathrm{R}^{2}\right.$ ), uji simultan (uji F), dan uji parsial (uji t). Hasil dari pengujian tersebut yang menjadi jawaban dari penelitian dan membuktikan atau menolak hipotesis yang telah diajukan.

\section{a. Analisis Koefisien Determinasi}

Analisis koefisien determinasi atau R2 dilakukan dengan tujuan untuk melihat seberapa besar variabel independen $(\mathrm{X})$ dapat menjelaskan variabel dependen (Y). Dimana rentang nilai dimulai dari 0-1. Semakin tinggi nilai mendekati angka 1, maka semakin besar variabel independen (X) dapat menjelaskan variabel dependen (Y).

Tabel 5. Hasil Estimasi

\begin{tabular}{|c|c|}
\hline Number of obs & 15 \\
\hline $\mathrm{F}(5,9)$ & 135.30 \\
\hline Prob $>\mathrm{F}$ & 0.0000 \\
\hline R-squared & 0.9869 \\
\hline Adj R-squared & 0.9796 \\
\hline Root MSE & .07078 \\
\hline
\end{tabular}

Sumber: Hasil Olahan Peneliti (2021)

Berdasarkan hasil yang telah diperoleh dalam Tabel 5, menunjukkan jika nilai R-squared sebesar 0,9869 atau $98,69 \%$. Hal ini berarti variabel independen (X) dalam penelitian ilmiah ini dapat menjelaskan variabel dependen (Y). Sehingga sisanya variabel dependen (Y) dapat dijelaskan melalui variabel independen (X) lainnya yang belum digunakan dalam penelitian ini.

\section{b. Uji Simultan (Uji F)}

Berikutnya akan dilakukan uji simultan atau uji F. Pengujian ini dilakukan guna untuk mengetahui apakah seluruh variabel independen (X) yang digunakan dalam penelitian ini memiliki pengaruh signifikan secara simultan terhadap variabel dependen (Y). Dimana dalam uji $\mathrm{F}$ ini syarat dalam menguji hipotesis yang diajukan, yaitu:

Jika nilai $($ Prob $>\mathrm{F})<$ alpha 0,05 maka $\mathrm{H}_{0}$ diterima Jika nilai $($ Prob $>\mathrm{F})>$ alpha 0,05 maka $\mathrm{H}_{0}$ ditolak

Berdasarkan Tabel 5, telah diketahui hasil akan nilai Prob > F yaitu sebesar 0,0000. Hal ini berarti nilai (Prob > F) < alpha 0,05 hal ini berarti $\mathrm{H}_{0}$ diterima. Sehingga dapat dinyatakan bahwa seluruh variabel independen $(\mathrm{X})$ memiliki pengaruh signifikan terhadap variabel dependen (Y). Variabel CAR, FDR, NPF, BOPO, dan pertumbuhan DPK pra merger Bank Umum Syariah anak perusahaan Bank BUMN secara bersama-sama memiliki pengaruh signifikan terhadap variabel Return on Asset. Sehingga setelah dilakukan merger, PT Bank Syariah Indonesia, Tbk sebagai hasil merger ketiga Bank Umum Syariah harus menjaga kinerja bank dengan baik. CAR, FDR, NPF, BOPO, dan pertumbuhan DPK harus selalu terjaga performansinya agar bank dapat mendapatkan ROA atau profitabilitas yang tinggi.

\section{c. Uji Parsial (Uji t)}

Pengujian berikutnya adalah uji parsial atau uji t. Dimana dalam pengujian ini, dilakukan identifikasi apakah setiap variabel independen (X) memiliki pengaruh terhadap variabel dependen $(\mathrm{Y})$.
Sehingga berikut adalah syarat untuk menguji hipotesis yang diajukan, yaitu:

Jika nilai $(\mathrm{P}>|\mathrm{t}|)<$ alpha 0,05 maka $\mathrm{H}_{0}$ diterima.

Jika nilai $(\mathrm{P}>|\mathrm{t}|)>$ alpha 0,05 maka $\mathrm{H}_{0}$ ditolak.

Tabel 6. Hasil Regresi

\begin{tabular}{|c|c|c|c|c|c|c|}
\hline $\mathrm{Y}$ & Coef. & $\begin{array}{l}\text { Std. } \\
\text { Err. }\end{array}$ & $\mathrm{t}$ & $\mathrm{P}>|\mathrm{t}|$ & \multicolumn{2}{|c|}{$\begin{array}{c}\text { [95\% Conf. } \\
\text { Interval] }\end{array}$} \\
\hline $\mathrm{X} 1$ & $\begin{array}{c}- \\
.0028 \\
288\end{array}$ & $\begin{array}{c}.0048 \\
096\end{array}$ & -0.59 & 0.571 & $\begin{array}{c}- \\
.013 \\
7089\end{array}$ & $\begin{array}{l}.0080 \\
514\end{array}$ \\
\hline $\mathrm{X} 2$ & $\begin{array}{c}.0185 \\
943 \\
\end{array}$ & $\begin{array}{c}.0045 \\
523 \\
\end{array}$ & 4.08 & 0.003 & $\begin{array}{l}.008 \\
2963 \\
\end{array}$ & $\begin{array}{c}.0288 \\
924 \\
\end{array}$ \\
\hline X3 & $\begin{array}{l}.0132 \\
207\end{array}$ & $\begin{array}{l}.0287 \\
139\end{array}$ & 0.46 & 0.656 & $\begin{array}{c}- \\
.051 \\
7347\end{array}$ & $\begin{array}{l}.0781 \\
761\end{array}$ \\
\hline $\mathrm{X} 4$ & $\begin{array}{c}- \\
.0991 \\
302 \\
\end{array}$ & $\begin{array}{c}.0077 \\
373\end{array}$ & -12.81 & 0.000 & $\begin{array}{c}- \\
.116 \\
6331 \\
\end{array}$ & $\begin{array}{c}- \\
.0816 \\
273 \\
\end{array}$ \\
\hline $\mathrm{X} 5$ & $\begin{array}{c}.0037 \\
171\end{array}$ & $\begin{array}{l}.0038 \\
274\end{array}$ & 0.97 & 0.357 & $\begin{array}{c}- \\
.004 \\
9411\end{array}$ & $\begin{array}{l}.0123 \\
752\end{array}$ \\
\hline $\begin{array}{c}\text { co } \\
\mathrm{ns}\end{array}$ & $\begin{array}{c}8.447 \\
934\end{array}$ & $\begin{array}{c}.6386 \\
003\end{array}$ & 13.23 & 0.000 & $\begin{array}{l}7.00 \\
3319\end{array}$ & $\begin{array}{c}9.892 \\
548\end{array}$ \\
\hline
\end{tabular}

Sumber: Hasil Olahan Peneliti (2021)

Setelah dilakukan regresi dengan menggunakan model Common Effect, diperoleh hasil seperti dalam Tabel 6. Hasil yang diperoleh dalam pengujian tersebut menunjukkan terdapat dua variabel independen (X) atau kinerja ketiga Bank Umum Syariah yang memiliki pengaruh signifikan terhadap ROA sebagai variabel dependen (Y). Namun tiga variabel independen $(\mathrm{X})$ lainnya menunjukkan bahwa tidak memiliki pengaruh signifikan terhadap variabel dependen (Y).

CAR yang disimbolkan sebagai X1 memiliki nilai $\mathrm{P}>|\mathrm{t}|$ sebesar 0,571 dan memiliki nilai koefisien sebesar -0,0028288. Hasil menunjukkan bahwa nilai $\mathrm{P}>|\mathrm{t}|$ yang diperoleh lebih besar dari alpha 0,05 . Maka berdasarkan hasil yang diperoleh, $\mathrm{H}_{0} 1$ dalam penelitian ini ditolak. Sehingga dalam penelitian ini menyimpulkan bahwa CAR tidak memiliki pengaruh yang signifikan terhadap ROA. Hasil penelitian yang diperoleh sejalan dengan penelitian yang dilakukan oleh Azmy (2018) dan Wardhani \& Amanah (2019). CAR yang merupakan rasio kecukupan modal selama periode 2015-2019 tidak memiliki pengaruh yang signifikan terhadap ROA. Bank yang harus menjaga kecukupan modal, harus berhati-hati dalam menggunakan modal untuk keperluan investasi, pembiayaan, dan hal-hal lainnya. Namun jika digunakan dengan tepat dan cermat, kegiatan tersebut dapat mendatangkan profitabilitas bagi bank. Sehingga dengan adanya merger ini, PT Bank Syariah Indonesia, Tbk diharapkan mampu menggunakan modal yang dimiliki dengan bijak untuk memperoleh lebih banyak laba.

Variabel selanjutnya yaitu FDR yang disimbolkan dengan X2. Dimana berdasarkan Tabel 6, nilai $\mathrm{P}>|\mathrm{t}|$ sebesar 0,003 dan memiliki nilai koefisien sebesar 0,0185943. Hasil menunjukkan bahwa nilai $\mathrm{P}>|\mathrm{t}|$ lebih kecil dari alpha 0,05. Maka hal ini 
menunjukkan bahwa hipotesis dalam penelitian ini yaitu $\mathrm{H}_{0} 2$ diterima. Sehingga dalam penelitian ini, FDR memiliki pengaruh yang signifikan dengan arah pengaruh positif. Hasil penelitian ini sejalan dengan penelitian yang dilakukan oleh Yanti (2020), Yusuf \& Surjaatmadja (2018), dan Azmy (2018). Menurut penelitian yang dilakukan oleh Yanti (2020), jika rasio FDR semakin besar, maka kesempatan untuk meningkatkan profitabilitas akan semakin besar. Berdasarkan hasil dari penelitian ini, menunjukkan setiap terjadi kenaikan FDR sebesar satu persen akan menaikkan rasio ROA sebesar $1,85943 \%$. Sehingga ke depannya PT Bank Syariah Indonesia, Tbk dapat menjaga kinerja FDR sesuai batas maksimum dan minimum yang telah ditetapkan.

Berdasarkan Tabel 6, NPF yang disimbolkan dengan X3 memiliki nilai $\mathrm{P}>|\mathrm{t}|$ sebesar 0,656 dan memiliki nilai koefisien sebesar 0,0132207. Hasil dari regresi menunjukkan bahwa nilai $\mathrm{P}\rangle|\mathrm{t}|$ lebih besar dari alpha 0,05 . Maka hipotesis dalam penelitian ini yaitu $\mathrm{H}_{0} 3$ ditolak. Sehingga dalam penelitian ini disimpulkan bahwa NPF secara parsial tidak memiliki pengaruh signifikan terhadap ROA. Hasil penelitian ini tidak sejalan dengan penelitian terdahulu yang dilakukan oleh Azmy (2018), Yanti (2020), dan Wardhani \& Amanah (2019). Dalam lima tahun terakhir NPF menunjukkan nilai rata-rata yang rendah atau menunjukkan kinerja yang baik. Rendahnya pembiayaan yang bermasalah tidak memberikan pengaruh signifikan terhadap ROA. Namun, PT Bank Syariah Indonesia, Tbk diharapkan ke depannya mampu menjaga kinerja bank dari risiko pembiayaan bermasalah. Jika NPF tinggi, maka akan mempengaruhi tingkat kesehatan bank. Dimana hal tersebut juga memberikan dampak akan hilangnya kepercayaan masyarakat.

BOPO yang disimbolkan sebagai X4 dalam Tabel 6, menunjukkan bahwa nilai $\mathrm{P}>|\mathrm{t}|$ sebesar 0,000 dan memiliki nilai koefisien sebesar -0,0991302. Hal ini menunjukkan bahwa nilai $\mathrm{P}>|\mathrm{t}|$ lebih kecil dari alpha 0,05. Maka hasil yang diperoleh menjawab hipotesis penelitian yaitu $\mathrm{H}_{0} 3$ diterima. Sehingga dapat disimpulkan bahwa BOPO memiliki pengaruh signifikan terhadap ROA dan memiliki arah pengaruh yang negatif. Hasil penelitian ini sejalan dengan penelitian yang dilakukan oleh Yusuf \& Surjaatmadja (2018) dan Azmy (2018). BOPO erat kaitannya dengan efisiensi perbankan. Dimana jika operasional bank semakin efisien, maka tingkat profitabilitas akan semakin tinggi (Yusuf \& Surjaatmadja, 2018). Berdasarkan koefisien dalam Tabel 6, menunjukkan bahwa setiap terjadi penurunan BOPO sebesar satu persen, maka akan terjadi kenaikan rasio ROA sebesar 9,91302\%. Sehingga untuk PT Bank Syariah Indonesia, Tbk diharapkan dapat menjaga stabilitas BOPO ke depannya, karena dalam lima tahun terakhir nilai rata-rata BOPO ketiga Bank Umum Syariah sebesar 90,71533\% dan berada sedikit di atas standar Bank Indonesia. Hal ini tentunya menjadi peringatan bagi bank baru agar nilai BOPO tetap di bawah batas maksimum.

Pertumbuhan DPK yang disimbolkan dengan $\mathrm{X} 5$ dalam Tabel 6 , menunjukkan bahwa nilai $\mathrm{P}>|\mathrm{t}|$ sebesar 0,357 dan memiliki nilai koefisien sebesar 0,0037171 . Hal ini berarti nilai $\mathrm{P}>|\mathrm{t}|$ lebih besar dari alpha 0,05 . Sehingga hipotesis dalam penelitian ini yaitu $\mathrm{H}_{0} 5$ ditolak. Maka dapat disimpulkan bahwa pertumbuhan DPK tidak memiliki pengaruh signifikan terhadap ROA. Hasil penelitian ini sejalan dengan penelitian yang dilakukan oleh Mahmudah \& Harjanti (2016) . Pertumbuhan DPK yang fluktuatif dan tidak seluruhnya disalurkan dalam bentuk pembiayaan dapat menjadi salah satu faktor mengenai tidak berpengaruhnya pertumbuhan DPK terhadap ROA (Mahmudah \& Harjanti, 2016). Sehingga diharapkan ke depannya PT Bank Syariah Indonesia, Tbk dapat meningkatkan pertumbuhan DPK menjadi lebih baik dan menggunakannya dengan bijak untuk pembiayaan.

\section{KESIMPULAN}

Kinerja ketiga Bank Umum Syariah anak perusahaan BUMN sebelum dimerger, selama lima tahun terakhir menunjukkan bahwa CAR dan NPF memiliki kinerja yang memuaskan. Dimana nilai ratarata CAR dapat melebihi dari standar minimum yaitu sebesar delapan persen. Nilai rata-rata NPF ketiga bank juga masih dalam batas aman karena berada di bawah batas maksimal standar yang ditetapkan Bank Indonesia. Namun untuk FDR dan BOPO berada sedikit melenceng dari batas minimum ataupun maksimum yang menjadi standar Bank Indonesia. FDR sendiri memiliki nilai rata-rata sedikit melenceng dari batas minimum yang telah ditetapkan. Sedangkan nilai rata-rata BOPO ketiga bank sedikit melebihi dari batas ambang maksimum. Berikutnya, pertumbuhan DPK rata-rata ketiga bank sebesar 15, 89333\%.

Kinerja ketiga bank sebelum dilakukannya merger, secara simultan memiliki pengaruh yang signifikan terhadap Return on Asset (ROA) yang merupakan penggambaran dari profitabilitas perbankan. Dimana berdasarkan hasil pengolahan data yang dilakukan, secara parsial terdapat dua rasio yang memiliki pengaruh terhadap ROA dan tiga rasio tidak memiliki pengaruh terhadap ROA. CAR secara parsial, tidak memiliki pengaruh signifikan terhadap ROA. FDR secara parsial, memiliki pengaruh signifikan terhadap ROA dan arah pengaruhnya positif. NPF secara parsial, tidak memiliki pengaruh signifikan terhadap ROA. BOPO secara parsial, memiliki pengaruh signifikan terhadap ROA dan arah pengaruhnya negatif. Sedangkan pertumbuhan DPK secara parsial, tidak memiliki pengaruh terhadap ROA.

Hal ini tentunya harus menjadi perhatian bagi PT Bank Syariah Indonesia Tbk sebagai perusahaan hasil merger tiga Bank Umum Syariah anak perusahaan Bank BUMN. Dimana bank baru diharapkan dapat menjaga rasio keuangan yang sudah baik. Selain itu perlu untuk meningkatkan kinerja bank untuk rasio keuangan yang belum maksimal.

Penelitian ini dilakukan guna mengukur kinerja pra merger tiga Bank Umum Syariah anak perusahaan Bank BUMN dan pengaruhnya terhadap 
ROA selama periode 2015-2019. Melalui penelitian ini, diharapkan menjadi pertimbangan bagi bank baru untuk memacu kinerja lebih baik ke depannya. Di samping itu, hasil dari penelitian ini juga menguatkan maupun menyanggah beberapa teori dari penelitian terdahulu yang menjadi acuan dalam penelitian ini. Sehingga ke depannya penelitian ini juga diharapkan menjadi literatur bagi peneliti selanjutnya.

Namun, penelitian ini juga masih memiliki batasan. Dimana bagi peneliti selanjutnya, diharapkan dapat menggali lebih dalam mengenai pengaruh kinerja perbankan terhadap ROA. Beberapa variabel lain yang belum digunakan dalam penelitian ini seperti Current Rasio, Quick Rasio, dan Debt to Equity Ratio (DER). Selain itu peneliti selanjutnya juga dapat meneliti mengenai pengaruh eksternal bank terhadap ROA. Diharapkan pula, bagi peneliti selanjutnya dapat meneliti perbandingan kinerja ketiga bank sebelum dan sesudah dilakukannya merger.

\section{REFERENSI}

Aulia, F. U. (2020). Akuntansi Bank Syariah (F. Firmansyah, Ed.). Pamekasan: IAIN Madura Press

Azmy, A. (2018). Analisis pengaruh rasio kinerja keuangan terhadap profitabilitas bank pembiayaan rakyat syariah di indonesia. Jurnal Akuntansi, $\quad 22(1), \quad 119-137$. https://doi.org/10.24912/ja.v22i1.326

Basuki, A. T., \& Prawoto, N. (2017). Analisis Regresi Dalam Penelitian Ekonomi \& Bisnis: Dilengkapi Aplikasi SPSS \& EVIEWS. Depok: PT Rajagrafindo Persada.

Bisnis Tempo. (2020). Gubernur BI Yakin Merger Bank Syariah BUMN Bakal Ciptakan Halal Value Chain. Retrieved January 20, 2021, from https://bisnis.tempo.co/read/1415508/gubernurbi-yakin-merger-bank-syariah-bumn-bakalciptakan-halal-value-chain/full \&view=ok

Brigham, E. F., \& Houston. (2006). Fundamental of Financial Management: Dasar-Dasar Manajemen Keuangan (10th ed.). Jakarta: Salemba Empat.

Danang, S. (2013). Metodologi Penelitian Akuntansi. Bandung: PT Refika Aditama.

Dendawijaya, L. (2009). Manajemen Perbankan. Jakarta: Ghalia Indonesia.

Gujarti, D. (2003). Ekonometrika Dasar. Jakarta: Erlangga.
Kasmir. (2012). Analisis Laporan Keuangan. Raja Grafindo, Jakarta.

Mahmudah, N., \& Harjanti, R. S. (2016). Analisis Capital Adequacy Ratio, Financing to Deposit Ratio, Non Performing Financing, dan Dana Pihak Ketiga terhadap Tingkat Profitabilitas Bank Umum Syariah Periode 2011-2013. Seminar Nasional Iptek Terapan, 1(1), 134143.

Margaretha, F. (2007). Manajemen Keuangan Bagi Industri \& Jasa. Jakarta: Grasindo.

Nisa Friskana, Y., \& Sudarsono, H. (2018). Pengaruh Kinerja Keuangan terhadap Return on Asset (ROA) Bank Syariah di Indonesia. Al-Amwal: Jurnal Ekonomi Dan Perbankan Syari'ah, 10(1), 18. https://doi.org/10.24235/amwal.v10i1.2759

Nuryanto, \& Pambuko. (2018). Eviews untuk Analisis Ekonometrika Dasar: Aplikasi dan Interpretasi. Magelang: Unimma Press.

Sanjaya, S. (2017). Analisis DuPont System DalamMengukur KinerjaKeuangan PT. TASPEN (Persero). Jurnal Riset Akuntansi Dan Bisnis, 17(1), 15-32.

Sekaran, U., \& Bougie, R. (2016). Research Methods for Business: A Skill Building Approach.

Suryani. (2012). Sistem Perbankan Islam Di Indonesia. Jurnal Muqtasid, 3(1), 111-131.

Tampubolon, S., \& Prima, A. P. (2020). PENGARUH RASIO KEUANGAN TERHADAP PROFITABILITAS PADA BANK PERKREDITAN RAKYAT DI KOTA BATAM. Jurnal AKRAB JUARA, 5(3), 101117. Retrieved from http://akrabjuara.com/index.php/akrabjuara/arti cle/view/1168/1025

Unaradjan, D. D. (2019). Metode Penelitian Kuantitatif. Jakarta: Universitas Katolik Indonesia Atma Jaya.

Wardhani, R. E., \& Amanah, L. (2019). Pengaruh Kinerja Keuangan dan Faktor Makro Ekonomi Terhadap Profitabilitas Bank Syariah. Jurnal Ilmu Dan Riset Akuntansi, 8(5).

Yanti, T. A. (2020). Analisis Pengaruh Risiko Kredit Terhadap Profitabilitas Bank Syariah Sumatera Utara. Ekonomi, Keuangan, Investasi Dan Syariah (EKUITAS), 1(2), 93-99.

Yusuf, M., \& Surjaatmadja, S. (2018). International Journal of Economics and Financial Issues Analysis of Financial Performance on Profitability with Non Performance Financing as Variable Moderation (Study at Sharia Commercial Bank in Indonesia Period 20122016). International Journal of Economics and Financial Issues, 8(4), 126-132. Retrieved from http:www.econjournals.com 